\title{
Oxidation-State Control of Nanoparticles Synthesized via Chemical Reduction Using Potential Diagrams
}

\section{$\operatorname{AUTHOR}(\mathrm{S}):$}

Yagi, Shunsuke; Nakanishi, Hidetaka; Ichitsubo, Tetsu; Matsubara, Eiichiro

\section{CITATION:}

Yagi, Shunsuke ...[et al]. Oxidation-State Control of Nanoparticles Synthesized via Chemical Reduction Using Potential Diagrams. JOURNAL OF THE ELECTROCHEMICAL SOCIETY 2009, 156(8): D321-D325

\section{ISSUE DATE:}

2009

URL:

http://hdl.handle.net/2433/109936

\section{RIGHT:}

(C) 2009 The Electrochemical Society 


\title{
Oxidation-State Control of Nanoparticles Synthesized via Chemical Reduction Using Potential Diagrams
}

\author{
Shunsuke Yagi, ${ }^{*, z}$ Hidetaka Nakanishi, Tetsu Ichitsubo, and Eiichiro Matsubara
}

Department of Materials Science and Engineering, Kyoto University, Kyoto 606-8501, Japan

\begin{abstract}
A general concept for oxidation-state control of nanoparticles synthesized via chemical reduction has been developed. By comparing kinetically determined mixed potential measured in reaction solution and thermodynamically drawn potential diagrams, e.g., potential-pH diagram, it is possible to know "what chemical species is stable in the reaction solution?." It is predicted from potential diagrams that nanoparticles in different oxidation states can be selectively synthesized by controlling mixed potential. This concept is verified by selectively synthesizing $\mathrm{Cu}$ and $\mathrm{Cu}_{2} \mathrm{O}$ nanoparticles from $\mathrm{CuO}$ aqueous suspension via chemical reduction using the concept as an example. The dependency of mixed potential on $\mathrm{pH}$ and temperature is discussed in detail for the selective synthesis of nanoparticles.

(C) 2009 The Electrochemical Society. [DOI: 10.1149/1.3151966] All rights reserved.
\end{abstract}

Manuscript submitted March 13, 2009; revised manuscript received May 8, 2009. Published June 19, 2009.

Copper $(\mathrm{Cu})$ nanoparticles are of great interest in various fields, specifically that of printable electronics. $\mathrm{Cu}$ interconnects less than $20 \mu \mathrm{m}$ wide can be made with a high resolution screen printer or a super inkjet printer using an ink which contains dense $\mathrm{Cu}$ nanoparticles. Cu nanoparticles have been synthesized by various reduction processes from cupric or cuprous compounds, including direct electrochemical reduction, ${ }^{1-3}$ chemical reduction, ${ }^{4-8}$ thermal reduction, ${ }^{9}$ sonochemical reduction, ${ }^{9,10}$ laser irradiation, ${ }^{11}$ and gamma radiolysis. ${ }^{12}$ Many of these methods are conducted in liquid phase and are often called "liquid-phase reduction." Liquid-phase reduction can generate nanoparticles in large quantity in a single process and also has the important advantage that nanoparticles can be formed in the presence of dispersing agents and no additional process for the addition of dispersing agents is required for the fabrication of inks to avoid the agglomeration.

Cuprous oxide $\left(\mathrm{Cu}_{2} \mathrm{O}\right)$ is a p-type semiconductor ${ }^{13}$ and is also a promising material with potential applications in solar energy conversion, microelectronics, magnetic storage, catalysis, and gas sensing. ${ }^{14} \mathrm{Cu}_{2} \mathrm{O}$ is also used for the investigation into Bose-Einstein condensation of excitons. ${ }^{15}$ Many methods have been reported to synthesize $\mathrm{Cu}_{2} \mathrm{O}$ nanoparticles, ${ }^{14,16,17}$ nanocubes, ${ }^{18,19}$ octahedral nanocages, ${ }^{20}$ and nanowires. ${ }^{21}$ For example, Muramatsu and Sugimoto reported that $\mathrm{Cu}_{2} \mathrm{O}$ particles with an average diameter of $270 \mathrm{~nm}$ were synthesized in large quantities from a $\mathrm{CuO}$ aqueous suspension using hydrazine as the reducing agent. ${ }^{16}$ Liu et al. formed $\mathrm{CuO}, \mathrm{Cu}_{2} \mathrm{O}$, and $\mathrm{Cu}$ nanoparticles using copper(II) acetylacetonate $\left[\mathrm{Cu}(\mathrm{acac})_{2}\right]$ as a precursor in oleylamine by controlling temperature. ${ }^{17}$ Although many synthesis methods of $\mathrm{Cu}$ and $\mathrm{Cu}_{2} \mathrm{O}$ nanoparticles have been reported, the synthesis processes have not been well discussed from the viewpoint of thermodynamics.

Against such a background, we propose a general concept for oxidation-state control of nanoparticles synthesized by chemical reduction using potential diagrams. In the present paper, the concept for oxidation-state control is described and verified by selectively synthesizing $\mathrm{Cu}$ and $\mathrm{Cu}_{2} \mathrm{O}$ nanoparticles from a $\mathrm{CuO}$ aqueous suspension by chemical reduction as an example. The advantage of this chemical reduction method in liquid phase is that abundant nanoparticles can be obtained for a short time by a simple operation. ${ }^{22,23} \mathrm{An}$ extremely small activity of $\mathrm{Cu}^{2+}$ aquo ion is achieved by using insoluble $\mathrm{CuO}$ powder as a $\mathrm{Cu}(\mathrm{II})$ ionic source, which is a key for the synthesis of nanosized particles.

\section{Theory}

In this section, a general concept for selective synthesis of nanoparticles will be introduced. All the data considered and used for thermodynamic calculation are listed in Table I..$^{24-27}$ The constant $a$

\footnotetext{
* Electrochemical Society Active Member.

${ }^{\text {z }}$ E-mail: syagi@mtl.kyoto-u.ac.jp
}

and coefficients $b$ and $c$ for the specific-heat capacity of hydrazine are only estimated by fitting the discrete data of the specific heat capacity of hydrazine in the temperature range from 100 to $600 \mathrm{~K}^{27}$

At any point within the reaction volume, several partial reactions occur in parallel. The potential at a point is determined at the value where the total of anodic currents $I_{\mathrm{a} \text {,total }}$ balances the total of cathodic currents $I_{c \text {,total }}$ unless current flows outside (Fig. 1). This potential is called the mixed potential. Stable chemical species in the reaction solution can be determined by comparing measured mixed potential and calculated potential diagrams, and chemical species synthesized can be changed by controlling mixed potential.

As an example, considering a reaction system for the synthesis of $\mathrm{Cu}$ or $\mathrm{Cu}_{2} \mathrm{O}$ nanoparticles from a $\mathrm{CuO}$ aqueous suspension of $\mathrm{pH} 9$ via hydrazine reduction, anodic reactions are mainly the oxidation reactions of hydrazine as follows

$$
\begin{gathered}
\mathrm{N}_{2} \mathrm{H}_{4}+4 \mathrm{OH}^{-} \rightarrow \mathrm{N}_{2}+4 \mathrm{H}_{2} \mathrm{O}+4 \mathrm{e} \\
\mathrm{N}_{2} \mathrm{H}_{4}+\mathrm{OH}^{-} \rightarrow \frac{1}{2} \mathrm{~N}_{2}+\mathrm{NH}_{3}+\mathrm{H}_{2} \mathrm{O}+\mathrm{e}
\end{gathered}
$$

Cathodic reactions are mainly the reaction of the deposition of $\mathrm{Cu}$ or $\mathrm{Cu}_{2} \mathrm{O}$ and hydrogen generation reaction as follows

Deposition of copper

$$
\mathrm{Cu}(\mathrm{II})+2 \mathrm{e} \rightarrow \mathrm{Cu}
$$

Deposition of cuprous oxide

$$
2 \mathrm{Cu}(\mathrm{II})+2 \mathrm{OH}^{-}+2 \mathrm{e} \rightarrow \mathrm{Cu}_{2} \mathrm{O}+\mathrm{H}_{2} \mathrm{O}
$$

Hydrogen generation

$$
2 \mathrm{H}_{2} \mathrm{O}+2 \mathrm{e} \rightarrow \mathrm{H}_{2}+2 \mathrm{OH}^{-}
$$

where $\mathrm{Cu}$ (II) represents all the copper(II) species and is distinguished from a copper(II) aquo ion, $\mathrm{Cu}^{2+}$. The overall deposition reactions of $\mathrm{Cu}$ and $\mathrm{Cu}_{2} \mathrm{O}$ in this system can be expressed using the following equations

Deposition of copper

$$
\begin{gathered}
\mathrm{CuO}+\frac{1}{2} \mathrm{~N}_{2} \mathrm{H}_{4} \rightarrow \mathrm{Cu}+\frac{1}{2} \mathrm{~N}_{2}+\mathrm{H}_{2} \mathrm{O} \\
\mathrm{CuO}+2 \mathrm{~N}_{2} \mathrm{H}_{4} \rightarrow \mathrm{Cu}+\mathrm{N}_{2}+2 \mathrm{NH}_{3}+\mathrm{H}_{2} \mathrm{O}
\end{gathered}
$$

Deposition of cuprous oxide

$$
\begin{gathered}
2 \mathrm{CuO}+\frac{1}{2} \mathrm{~N}_{2} \mathrm{H}_{4} \rightarrow \mathrm{Cu}_{2} \mathrm{O}+\frac{1}{2} \mathrm{~N}_{2}+\mathrm{H}_{2} \mathrm{O} \\
2 \mathrm{CuO}+2 \mathrm{~N}_{2} \mathrm{H}_{4} \rightarrow \mathrm{Cu}_{2} \mathrm{O}+\mathrm{N}_{2}+2 \mathrm{NH}_{3}+\mathrm{H}_{2} \mathrm{O}
\end{gathered}
$$

Figure 2 shows potential-pH diagrams (Pourbaix diagrams) ${ }^{28}$ drawn at an equilibrium activity of the $\mathrm{Cu}^{2+}$ aquo ion in the presence of abundant $\mathrm{CuO}$ at $\mathrm{pH}$ 9. In this case, the equilibrium activity of $\mathrm{Cu}^{2+}$ aquo ion can be determined by considering an equilibrium reaction 
Table I. List of standard heat of formation, entropy at $298 \mathrm{~K}$ and $1 \mathrm{~atm}$, and specific heat at constant pressure (1 atm) considered and used for themodynamic calculation.

\begin{tabular}{|c|c|c|c|c|c|c|}
\hline \multirow[b]{2}{*}{ Chemical species } & \multirow{2}{*}{$\begin{array}{l}\text { Standard heat of formation } \\
\left(\mathrm{kJ} \mathrm{mol}^{-1}\right)\end{array}$} & \multirow{2}{*}{$\begin{array}{l}\text { Standard entropy } \\
\left(\mathrm{J} \mathrm{K}^{-1} \mathrm{~mol}^{-1}\right)\end{array}$} & \multicolumn{3}{|c|}{$\begin{array}{l}\text { Specific heat at constant pressure } \\
\left(\mathrm{J} \mathrm{K}^{-1} \mathrm{~mol}^{-1}\right) \\
C_{\mathrm{p}}=a+b \times 10^{-3} \mathrm{~T}+c \times 10^{5} \mathrm{~T}^{2}\end{array}$} & \multirow[b]{2}{*}{ References } \\
\hline & & & $a$ & $b$ & $c$ & \\
\hline $\mathrm{H}^{+}(\mathrm{aq})$ & 0.0 & 0.0 & 129.7 & - & - & 24 and 25 \\
\hline $\mathrm{Cu}^{2+}(\mathrm{aq})$ & 64.4 & -98.7 & 267.8 & - & - & 24 and 25 \\
\hline $\mathrm{H}_{2} \mathrm{O}(\mathrm{l})$ & -285.8 & 70.0 & 75.4 & - & - & 26 \\
\hline $\mathrm{H}_{2}(\mathrm{~g})$ & 0.0 & 130.6 & 27.3 & 3.3 & 0.50 & 26 \\
\hline $\mathrm{Cu}(\mathrm{s})$ & 0.0 & 33.1 & 22.6 & 6.3 & - & 26 \\
\hline $\mathrm{Cu}_{2} \mathrm{O}(\mathrm{s})$ & -167.4 & 93.1 & 62.3 & 23.9 & - & 26 \\
\hline $\mathrm{CuO}(\mathrm{s})$ & -155.2 & 42.7 & 38.8 & 20.1 & - & 26 \\
\hline $\mathrm{N}_{2}(\mathrm{~g})$ & 0.0 & 191.5 & 27.9 & 4.3 & - & 26 \\
\hline $\mathrm{NH}_{3}(\mathrm{~g})$ & -45.9 & 192.7 & 37.3 & 18.7 & -6.49 & 26 \\
\hline $\mathrm{N}_{2} \mathrm{H}_{4}$ (1) & 50.6 & 121.6 & 72.7 & 87.2 & 0.60 & 27 \\
\hline
\end{tabular}

of $\mathrm{Cu}^{2+}$ and $\mathrm{CuO}$, where the activities of $\mathrm{CuO}$ and $\mathrm{H}^{+}$are assigned to 1 and $10^{-9}$, respectively. The species $\mathrm{Cu}^{2+}, \mathrm{CuO}, \mathrm{Cu}_{2} \mathrm{O}$, and $\mathrm{Cu}$ are only considered, and oxyanions of copper, such as $\mathrm{HCuO}_{2}^{-}$and $\mathrm{CuO}_{2}^{2-}$, or hydroxyanions of copper, ${ }^{29} \mathrm{Cu}(\mathrm{OH})_{3}^{-}$and $\mathrm{Cu}(\mathrm{OH})_{4}^{2-}$, are not considered. This is only for simplicity because the oxidationreduction potentials of $\mathrm{CuO} / \mathrm{Cu}_{2} \mathrm{O}$ and $\mathrm{Cu}_{2} \mathrm{O} / \mathrm{Cu}$ redox pairs at $\mathrm{pH} 9$ are important for the prediction of synthesized chemical species in this case. For instance, the oxidation-reduction potentials of $\mathrm{Cu}_{2} \mathrm{O}$ and any $\mathrm{Cu}$ (II) ionic species in equilibrium are the same at a constant $\mathrm{pH}$ and temperature in the presence of abundant solid $\mathrm{CuO}$ powder, resulting in the same oxidation-reduction potential of the $\mathrm{Cu}_{2} \mathrm{O} / \mathrm{Cu}$ redox pair. The equilibrium activity of $\mathrm{Cu}^{2+}$ aquo ion changes with $\mathrm{pH}$ and therefore, the potential- $\mathrm{pH}$ diagram is only valid at the constant $\mathrm{pH}$ considered. Fortunately, $\mathrm{pH}$ of the solution barely changes during the reaction in the present method, ${ }^{22}$ and it is possible to determine the most stable chemical species throughout the reaction by comparing the measured mixed potential to the vertical line of a constant $\mathrm{pH}$ (in this case, $\mathrm{pH}$ 9) in the potential- $\mathrm{pH}$ diagrams. In other words, the kind of chemical species synthesized can be controlled if the mixed potential is changed as expected. Next, factors to change the mixed potential are discussed.

As described above, the mixed potential is determined by the balance of each partial current. Therefore, the mixed potential is changed when the oxidation-reduction potential of each partial reaction is changed. The oxidation-reduction potential $E$ at a temperature $T$ and $1 \mathrm{~atm}$ is calculated using the following Nernst equation

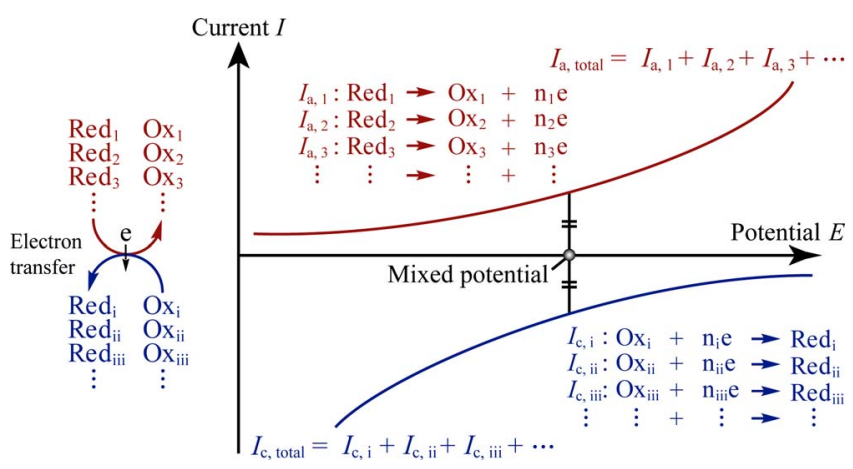

Figure 1. (Color online) Schematic potential-current curves: Mixed potential is determined at the value where the total of anodic currents $I_{\mathrm{a} \text {,total }}$ balances the total of cathodic currents $I_{c \text {,total }}$ unless current flows outside.

$$
\begin{aligned}
E= & -\frac{\Delta G_{T}}{n F}=-\frac{1}{n F}\left(\Delta G_{T}^{0}+R T \ln Q\right) \\
= & -\frac{1}{n F}\left[\left(\Delta H_{T}^{0}-T \Delta S_{T}^{0}\right)+R T \ln Q\right] \\
= & -\frac{1}{n F}\left[\left(\Delta H_{298}^{0}+\int_{298}^{T} \Delta C_{\mathrm{p}} d T\right)-T\left(\Delta S_{298}^{0}+\int_{298}^{T} \frac{\Delta C_{\mathrm{p}}}{T} d T\right)\right. \\
& +R T \ln Q]
\end{aligned}
$$

where $\Delta G_{T}$ is the change in Gibbs free energy at a temperature $T$ and $1 \mathrm{~atm}, \Delta G_{T}^{0}, \Delta H_{T}^{0}$, and $\Delta S_{T}^{0}$ are the changes in Gibbs free energy, enthalpy, and entropy that accompanies the formation of 1 mole of a product from its component elements at a temperature $T$ and $1 \mathrm{~atm}$, respectively, $\Delta C_{P}$ is the change in specific heat at constant pressure (1 atm), $n$ is the number of electrons transferred in the half-cell reaction, $F$ is the Faraday constant, $R$ is the gas constant, $T$ is the absolute temperature in kelvins, and $Q$ is the reaction quotient. ${ }^{24-27}$ Table II shows calculated results of the oxidation-reduction potentials of all the partial reactions considered. Activity of each chemical in the reaction quotient is substituted by the same value as the actual molar concentration of the chemical in the present reaction system, and specifically, both activities of $\mathrm{H}_{2}$ and $\mathrm{NH}_{3}$, which cannot be determined exactly, are substituted by $10^{-6}$ to obtain referential values. As shown in Table II, all the oxidation-reduction potentials shift to the negative direction with increasing both $\mathrm{pH}$ and temperature, which can result in a negative shift of the mixed potential Even the oxidation-reduction potentials of Reactions 3 and 4 shift to the negative direction with increasing $\mathrm{pH}$; the former is normally constant with $\mathrm{pH}$ and the latter increases with the increase in $\mathrm{pH}$ at a constant activity of $\mathrm{Cu}(\mathrm{II})$ ions. This is because, for example, the equilibrium activity of $\mathrm{Cu}^{2+}$ aquo ion decreases with increasing $\mathrm{pH}$ under the coexistence of abundant solid $\mathrm{CuO}$ in equilibrium, which brings about the negative shift of the oxidation-reduction potentials of Reactions 3 and 4 . Thus, possibly the mixed potential is shifted to the negative direction with increasing $\mathrm{pH}$ and temperature because the oxidation-reduction potentials of all the partial reactions shift to the negative direction. Consequently, factors to change the mixed potential are $\mathrm{pH}$ and temperature, which are easily controllable.

\section{Experimental}

Procedure.- Reaction solutions were prepared using cupric oxide $(\mathrm{CuO})$ (Kanto Chemical, Inc.), sodium hydroxide $(\mathrm{NaOH})$, hydrazine monohydrate $\left(\mathrm{N}_{2} \mathrm{H}_{4} \cdot \mathrm{H}_{2} \mathrm{O}\right)$ (Nacalai Tesque, Inc.), and gelatin (Jellice Co. Ltd., P459) as received. All chemicals except for 

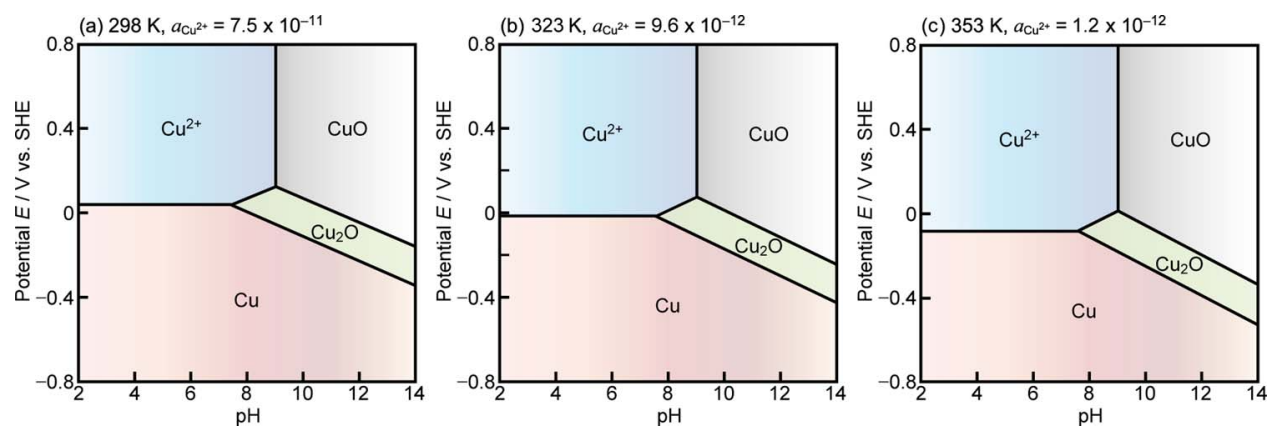

Figure 2. (Color online) Potential-pH diagrams drawn at the equilibrium activities of $\mathrm{Cu}^{2+}$ aquo ion at $\mathrm{pH} 9$ and (a) 298, (b) 323 , and (c) $353 \mathrm{~K}$ considering the species $\mathrm{Cu}^{2+}, \mathrm{CuO}, \mathrm{Cu}_{2} \mathrm{O}$, and $\mathrm{Cu}$. Oxyanions of copper, $\mathrm{HCuO}_{2}^{-}$and $\mathrm{CuO}_{2}^{2-}$, or hydroxyanions of copper, $\mathrm{Cu}(\mathrm{OH})_{3}^{-}$and $\mathrm{Cu}(\mathrm{OH})_{4}^{2-}$, are not considered for simplicity. These potential-pH diagrams are only valid at the vertical line of $\mathrm{pH} 9$ because the equilibrium activity of $\mathrm{Cu}^{2+}$ aquo ion changes with $\mathrm{pH}$ in this system. gelatin were of reagent grade. Gelatin was added as a dispersing agent to avoid agglomeration and for the suppression of particle growth. Gelatin blocked oxygen and was also effective in preventing the oxidation of the resulted nanoparticles. Reactions were conducted in a Pyrex beaker $250 \mathrm{~cm}^{3}$ in capacity by the following procedure. First, a $\mathrm{CuO}$ colloidal aqueous suspension was prepared by dispersing 0.060 mole of $\mathrm{CuO}$ particles in $42.0 \mathrm{~cm}^{3}$ of distilled water using ultrasound. Next, $18.0 \mathrm{~cm}^{3}$ of $10 \mathrm{wt} \%$ gelatin aqueous solution was added into the solution as a dispersing agent. The initial $\mathrm{pH}$ of the mixed solution was adjusted to the reaction $\mathrm{pH}(9.0-$ $12.0)$ at $298 \mathrm{~K}$ by $1.0 \mathrm{~mol} \mathrm{dm}{ }^{-3}$ sodium hydroxide aqueous solution with a $\mathrm{pH}$ meter (Horiba, Ltd., D-21). The temperature of the solution was kept at the reaction temperature $(298-353 \mathrm{~K})$ in a water bath with nitrogen gas bubbling $\left(50 \mathrm{~cm}^{3} \mathrm{~min}^{-1}\right)$, which started $30 \mathrm{~min}$ before the reaction and lasted throughout the reaction to eliminate the effect of dissolved oxygen. The solution was agitated at a rate of $500 \mathrm{rpm}$ with a magnetic stirring unit. Then, $42.0 \mathrm{~cm}^{3}$ of $1.43 \mathrm{~mol} \mathrm{dm}^{-3}$ hydrazine aqueous solution was added to $18.0 \mathrm{~cm}^{3}$ of $10 \mathrm{wt} \%$ gelatin aqueous solution, and this solution was kept at the reaction temperature $(298-353 \mathrm{~K})$ with nitrogen gas bubbling $\left(50 \mathrm{~cm}^{3} \mathrm{~min}^{-1}\right)$ for $30 \mathrm{~min}$. The initial $\mathrm{pH}$ of the hydrazine solution was adjusted to the reaction $\mathrm{pH}(9.0-12.0)$ by $1.0 \mathrm{~mol} \mathrm{dm}{ }^{-3}$ sodium hydroxide aqueous solution at $298 \mathrm{~K}$. Next, the hydrazine solution was added to the $\mathrm{CuO}$ aqueous suspension as a reducing agent to start the reaction. The total amount of the reaction suspension was $120.0 \mathrm{~cm}^{3}$, and thus the reaction suspension was $0.50 \mathrm{~mol} \mathrm{dm}^{-3}$ hydrazine aqueous solution with $0.50 \mathrm{~mol} \mathrm{dm}^{-3}$ dispersed $\mathrm{CuO}$. Gelatin was not added in the reaction suspension at $298 \mathrm{~K}$ because gelatin became a gel at $298 \mathrm{~K}$, inhibiting the reaction.

The crystalline structure of precipitates was investigated by X-ray diffraction (XRD: MAC Science Co., Ltd., M03XHF22) using a molybdenum $\mathrm{X}$-ray tube. The morphology of precipitates was observed using a field-emission scanning electron microscope (JEOL Ltd., JSM-6500F). The immersion potential of Au-sputtered round quartz-crystal substrates $5.0 \mathrm{~mm}$ diameter was measured during several experimental runs by a potentiostat/galvanostat (Hokuto Denko Co., Ltd., HA-151), and the authors assumed that the mea- sured immersion potential was almost the same as the mixed potential in reaction suspension in this system. $\mathrm{A} \mathrm{Ag} / \mathrm{AgCl}$ electrode (Horiba, Ltd., 2565A-10T) was used as a reference electrode, and the internal liquid, $3.33 \mathrm{~mol} \mathrm{dm}^{-3} \mathrm{KCl}$ aqueous solution, was replaced for each experimental run. The measured potential was converted to values vs standard hydrogen electrode (SHE) using the following empirical equation given by Horiba, Ltd.: The potential of the reference electrode could be expressed as a function of temperature $T(\mathrm{~K})$ as $E(\mathrm{mV})$ vs $\mathrm{SHE}=+206-0.7(T-298)$.

\section{Results and Discussion}

In the present method, $\mathrm{pH}$ of the reaction suspension is initially adjusted at $298 \mathrm{~K}$, and actual $\mathrm{pH}$ at reaction temperatures differs from the adjusted value. This is ascribable to the change in the ionic product for water, $K_{\mathrm{w}}=\left[\mathrm{H}^{+}\right]\left[\mathrm{OH}^{-}\right]$; for example, the value of $K_{\mathrm{w}}$ $\left(\mathrm{mol}^{2} \mathrm{dm}^{-6}\right)$ is $1.008 \times 10^{-14}$ at $298.15 \mathrm{~K}$ and $5.476 \times 10^{-14}$ at $323.15 \mathrm{~K}$. Figure 3 shows the change with temperature in $\mathrm{pH}$, which is initially adjusted to 9.0 at $298 \mathrm{~K}$. pH linearly decreases with increasing temperature, and the values are 9.0 at $298 \mathrm{~K}, 8.5$ at $323 \mathrm{~K}$, and 7.6 at $353 \mathrm{~K}$. Figure 4 shows the change in the mixed potential during the reaction for $2 \mathrm{~h}$. At the same temperature of $323 \mathrm{~K}$, the mixed potential at $\mathrm{pH} 10.4$ (Fig. 4d) is lower than that at $\mathrm{pH} 8.5$ (Fig. 4b). This agrees well with the discussion in the Theory section. Moreover, the mixed potential shifts to the negative direction with increasing temperature although $\mathrm{pH}$ slightly decreases, indicating that the mixed potential can be lowered just by increasing temperature without fixing $\mathrm{pH}$.

By comparing the mixed potential and the potential-pH diagrams shown in Fig. 5, the mixed potential was in the stability region of $\mathrm{Cu}_{2} \mathrm{O}$ both at $\mathrm{pH}$ 9.0, $298 \mathrm{~K}$ (Fig. 5a) and pH 8.5, $323 \mathrm{~K}$ (Fig. 5b), whereas the mixed potential was in the stability region of metal $\mathrm{Cu}$ at $\mathrm{pH} 7.6,353 \mathrm{~K}$ (Fig. 5c). Figure 6 shows the change with time in $\mathrm{XRD}$ patterns of precipitates during the reaction for $2 \mathrm{~h}$. CuO powder was reduced to $\mathrm{Cu}_{2} \mathrm{O}$ after $1 \mathrm{~h}$ at $\mathrm{pH} 9.0,298 \mathrm{~K}$ although slight $\mathrm{Cu}$ peaks are recognized in the XRD pattern taken at $2 \mathrm{~h}$. At $\mathrm{pH}$ 7.6, $353 \mathrm{~K}, \mathrm{CuO}$ powder was completely reduced to metal $\mathrm{Cu}$ after $0.5 \mathrm{~h}$. These results are almost consistent with the result that the

Table II. List of oxidation-reduction potentials calculated for partial reactions considered in this system. Activity of each chemical species is substituted by the actual molar concentration in the present reaction system, and specifically, activities of $\mathbf{H}_{2}$ and $\mathrm{NH}_{3}$ are both substituted by $10^{-6}$ to obtain reference values. All the oxidation-reduction potentials calculated shift to the negative direction with increasing both $\mathrm{pH}$ and temperature, which can result in a negative shift of the mixed potential.

Oxidation-reduction potential at $\mathrm{pH} 9$ (V vs SHE)
Oxidation-reduction potential at $\mathrm{pH} 12$ (V vs SHE)

\begin{tabular}{|c|c|c|c|c|c|c|c|}
\hline Partial reaction & $298 \mathrm{~K}$ & $323 \mathrm{~K}$ & $353 \mathrm{~K}$ & $298 \mathrm{~K}$ & $323 \mathrm{~K}$ & $353 \mathrm{~K}$ & Reaction no. \\
\hline $\mathrm{N}_{2}+4 \mathrm{H}_{2} \mathrm{O}+4 \mathrm{e}=\mathrm{N}_{2} \mathrm{H}_{4}+4 \mathrm{OH}^{-}$ & -0.92 & -0.98 & -1.06 & -1.09 & -1.17 & -1.27 & 1 \\
\hline$\frac{1}{2} \mathrm{~N}_{2}+\mathrm{NH}_{3}+\mathrm{H}_{2} \mathrm{O}+\mathrm{e}=\mathrm{N}_{2} \mathrm{H}_{4}+\mathrm{OH}^{-}$ & -2.59 & -2.72 & -2.88 & -2.777 & -2.91 & -3.09 & 2 \\
\hline $2 \mathrm{Cu}(\mathrm{II})+2 \mathrm{OH}^{-}+2 \mathrm{e}=\mathrm{Cu}_{2} \mathrm{O}+\mathrm{H}_{2} \mathrm{O}$ & 0.13 & 0.07 & 0.01 & -0.05 & -0.12 & -0.20 & 4 \\
\hline $2 \mathrm{H}_{2} \mathrm{O}+2 \mathrm{e}=\mathrm{H}_{2}+2 \mathrm{OH}^{-}$ & -0.18 & -0.19 & -0.21 & -0.35 & -0.38 & -0.42 & 5 \\
\hline
\end{tabular}




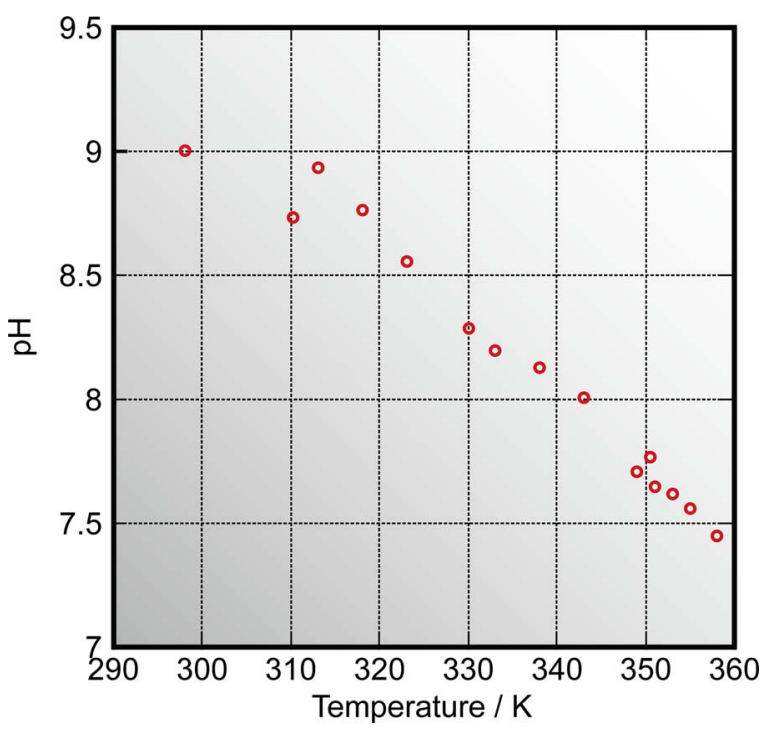

Figure 3. (Color online) Change in $\mathrm{pH}$ of the reaction suspension with temperature; $\mathrm{pH}$ of the reaction suspension was initially adjusted to 9.0 at $298 \mathrm{~K}$.

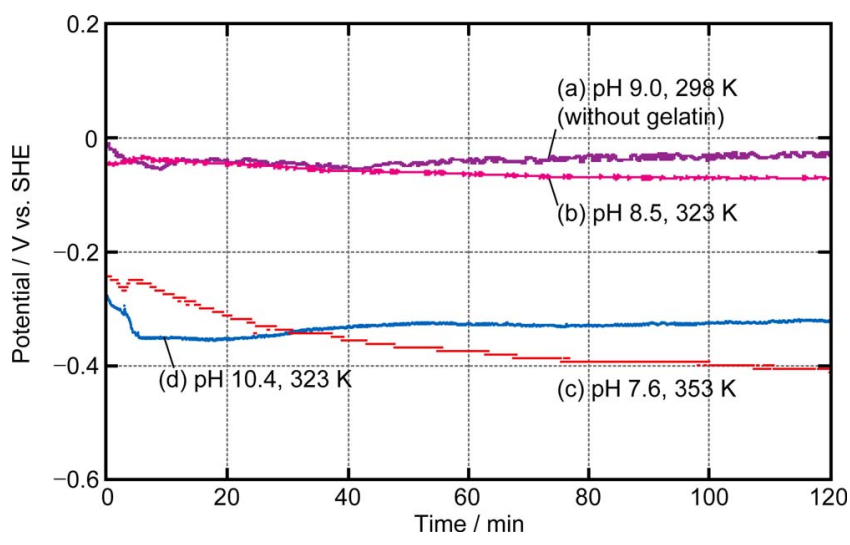

Figure 4. (Color online) Mixed potentials measured during the reaction at (a) $\mathrm{pH} 9.0,298 \mathrm{~K}$ (without gelatin), (b) $\mathrm{pH} 8.5,323 \mathrm{~K}$, (c) $\mathrm{pH} 7.6,353 \mathrm{~K}$, and (d) $\mathrm{pH} 10.4,323 \mathrm{~K}$.
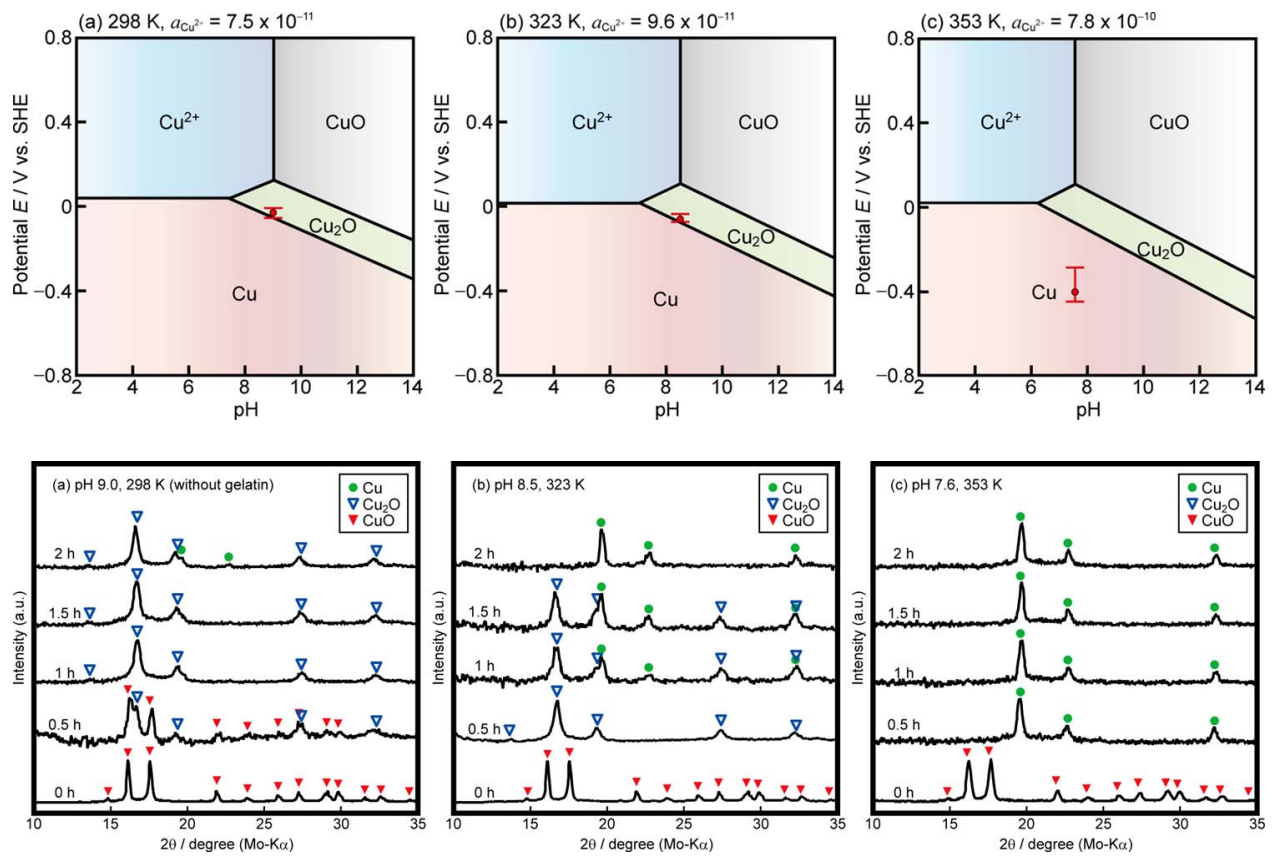

mixed potentials measured at $\mathrm{pH} 7.6,353 \mathrm{~K}$ and $\mathrm{pH} 9.0,298 \mathrm{~K}$ were always in the stability region of $\mathrm{Cu}$ and $\mathrm{Cu}_{2} \mathrm{O}$, respectively. In contrast, at $\mathrm{pH} 8.5,323 \mathrm{~K}$, all $\mathrm{CuO}$ powder was reduced to $\mathrm{Cu}_{2} \mathrm{O}$ after $0.5 \mathrm{~h}$ and then the resulting $\mathrm{Cu}_{2} \mathrm{O}$ was gradually reduced to $\mathrm{Cu}$ metal. This is not consistent with the measurement result of the mixed potential. By carefully observing the change in the mixed potential at $\mathrm{pH} 8.5,323 \mathrm{~K}$, the initial mixed potential is $-0.045 \mathrm{~V}$ vs SHE and in the stability region of $\mathrm{Cu}_{2} \mathrm{O}$, and the mixed potential gradually decreases to $-0.072 \mathrm{~V}$ with reaction time, which is just beside the calculated oxidation-reduction potential of $\mathrm{Cu}_{2} \mathrm{O} / \mathrm{Cu}$, $-0.077 \mathrm{~V}$ vs SHE; i.e., as $\mathrm{CuO}$ is reduced to $\mathrm{Cu}_{2} \mathrm{O}$, the mixed potential approaches the oxidation-reduction potential of $\mathrm{Cu}_{2} \mathrm{O} / \mathrm{Cu}$ redox pair, where $\mathrm{Cu}_{2} \mathrm{O}$ and $\mathrm{Cu}$ coexist. Nevertheless, the mixed potential is $5 \mathrm{mV}$ higher than the calculated oxidation-reduction potential of $\mathrm{Cu}_{2} \mathrm{O} / \mathrm{Cu}$ and it is difficult to adequately elaborate on the result that the deposition of $\mathrm{Cu}$ completely proceeded after $2 \mathrm{~h}$. Here, $\mathrm{pH}$ of the solution tends to slightly decrease during the reaction, although ideally, pH would not be changed by taking into account the overall reaction in the present reaction system. For example, $\mathrm{pH}$ actually decreased from 8.5 to approximately 8 at $323 \mathrm{~K}$, resulting in a slight increase in the oxidation-reduction potential of a $\mathrm{Cu}_{2} \mathrm{O} / \mathrm{Cu}$ redox pair. Furthermore, there can be a slight difference between the mixed potential measured using $\mathrm{Au}$ electrode and the actual mixed potential in the reaction suspension. Therefore, the actual mixed potential is slightly lower than the oxidation-reduction potential of the $\mathrm{Cu}_{2} \mathrm{O} / \mathrm{Cu}$ redox pair. Nonetheless, a Au electrode is preferable for the measurement of the mixed potential in this reaction system because a $\mathrm{Au}$ electrode does not have intense catalytic activity for a specific partial reaction possible in the reaction system, $^{30,31}$ and the effect of the immersion of the Au substrate is extremely low.

The scanning electron microscopy (SEM) images of the precipitates obtained by the reaction are shown in Fig. 7. Relatively large $\mathrm{Cu}_{2} \mathrm{O}$ particles with an average diameter of $475 \mathrm{~nm}$ are observed in the precipitates obtained after $2 \mathrm{~h}$ at $\mathrm{pH} 9.0,298 \mathrm{~K}$. These large particles are attributable to the absence of gelatin. At pH 8.5, $323 \mathrm{~K}$, $\mathrm{Cu}_{2} \mathrm{O}$ particles with an average diameter of $97 \mathrm{~nm}$ are observed after $0.5 \mathrm{~h}$ and $\mathrm{Cu}$ particles with an average diameter of $82 \mathrm{~nm}$ are observed after $2 \mathrm{~h}$. $\mathrm{Cu}$ particles with an average diameter of $55 \mathrm{~nm}$ are observed after $2 \mathrm{~h}$ at $353 \mathrm{~K}$. As above, the mean particle size is decreased with the increase in temperature because nucleation site increases with the increase in temperature and an inordinate number 


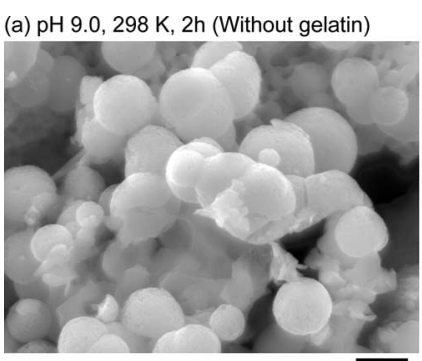

(b) $\mathrm{pH} 8.5,323 \mathrm{~K}, 2 \mathrm{~h}$

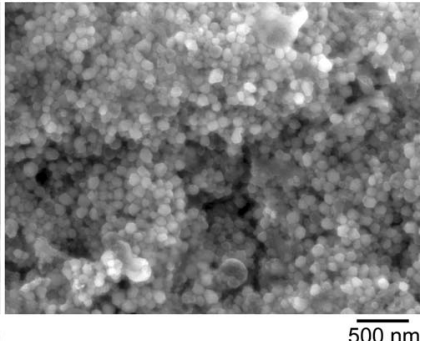

(c) $\mathrm{pH} 7.6,353 \mathrm{~K}, 2 \mathrm{~h}$

$\overline{500 \mathrm{~nm}}$

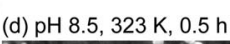

$\overline{500 \mathrm{~nm}}$
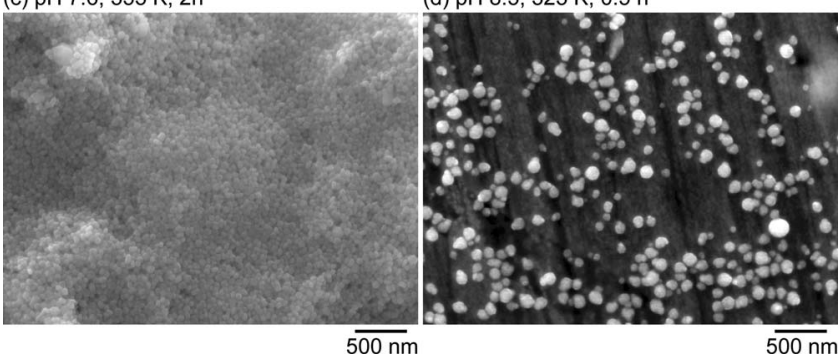

Figure 7. SEM images of precipitates obtained by the reaction at (a) $\mathrm{pH} 9.0$, $298 \mathrm{~K}$ (without gelatin), (b) $\mathrm{pH} 8.5,323 \mathrm{~K}$, (c) $\mathrm{pH} 7.6,353 \mathrm{~K}$ for $2 \mathrm{~h}$, and (d) $\mathrm{pH} 8.5,323 \mathrm{~K}$ for $0.5 \mathrm{~h}$.

of nucleation sites at high temperatures leads to the absence of reactant ions $[\mathrm{Cu}(\mathrm{II})$ or $\mathrm{Cu}(\mathrm{I})$ ions] for the growth. Table III shows the crystallite sizes of particles obtained by chemical reduction, which were calculated by Scherrer's equation using the peak width at halfmaximum of 111 peaks at $2 \theta=16.5^{\circ}$ for $\mathrm{Cu}_{2} \mathrm{O}$ and $19.6^{\circ}$ for $\mathrm{Cu}$. The crystallite sizes are all much smaller than those of particles observed, and possibly these particles are all polycrystalline. This result indicates that the deposition rate of $\mathrm{Cu}$ and $\mathrm{Cu}_{2} \mathrm{O}$ nanoparticles is significantly large for the formation of single-crystal nanoparticles in the present method. The large reaction rate is industrially favorable. Single-crystal $\mathrm{Cu}$ and $\mathrm{Cu}_{2} \mathrm{O}$ nanoparticles can be obtained by regulating the deposition of nanoparticles using a milder reducing agent than hydrazine or adding a strong complexing agent.

\section{Conclusions}

A general concept for oxidation-state control of nanoparticles synthesized via chemical reduction has been developed. Through the present work, we have obtained the following results.

Mixed potential is the most effective indicator of solution circumstances, indicating the most stable chemical species in the reaction solution, i.e., thermodynamic considerations in conjunction with monitoring of mixed potential is useful for the in situ predic-

\section{Table III. Crystallite sizes of particles obtained by chemical re- duction. Calculation was conducted using Scherrer's equation} with the half-width of 111 peak.

\begin{tabular}{lccc} 
& $\begin{array}{c}\text { Half-width } \\
(\mathrm{deg})\end{array}$ & $\begin{array}{c}\text { Diffraction } \\
\text { angle } 2 \theta \\
(\mathrm{deg})\end{array}$ & $\begin{array}{c}\text { Crystallite } \\
\text { size } \\
(\mathrm{nm})\end{array}$ \\
\hline pH 9.0, 298 K, 2 h $\left(\mathrm{Cu}_{2} \mathrm{O}\right)$ & 0.359 & 16.5 & 10.3 \\
pH 8.5, 323 K, 2 h $\left(\mathrm{Cu}^{2}\right)$ & 0.209 & 19.6 & 17.8 \\
pH 7.6, 353 K, 2 h $(\mathrm{Cu})$ & 0.252 & 19.6 & 14.8 \\
pH 8.5, 323 K, 0.5 h $\left(\mathrm{Cu}_{2} \mathrm{O}\right)$ & 0.431 & 16.5 & 8.6
\end{tabular}

tion of "what chemical species will be synthesized." Solution $\mathrm{pH}$ and temperature are the factors which affect the mixed potential, and thus, the most stable chemical species can be changed by $\mathrm{pH}$ and temperature. Specifically in this system, the mixed potential decreases with the increase both in $\mathrm{pH}$ and temperature. Using this concept, we demonstrated the selective synthesis of $\mathrm{Cu}$ and $\mathrm{Cu}_{2} \mathrm{O}$ nanoparticles by controlling mixed potential. This concept is also effective in other reaction systems where thermodynamic data are available.

\section{Acknowledgments}

The authors thank Shohei Shiomi from Kyoto University for his experimental help. This research was supported by a grant-in-aid for Knowledge Cluster Initiative (Kyoto Nanotechnology Cluster), Grant-in-Aid for the Global COE Program (International Center for Integrated Research and Advanced Education in Materials Science), and Grant-in-Aid for Young Scientists (B 20760505), all from the Japan Society for the Promotion of Science, Ministry of Education, Culture, Sports, Science and Technology of Japan. This research was also supported by the Kurata Memorial Hitachi Science and Technology Foundation and Shorai Foundation for Science and Technology.

Kyoto University assisted in meeting the publication costs of this article.

\section{References}

1. W. K. Han, K. W. Choi, G. H. Hwang, S. J. Hong, J. S. Lee, and S. G. Kang, Appl Surf. Sci., 252, 2832 (2006).

L. Huang, H. Jiang, J. Zhang, Z. Zhang, and P. Zhang, Electrochem. Commun., 8, $262(2006)$

3. L. Yu, H. Sun, J. He, D. Wang, X. Jin, X. Hu, and G. Z. Chen, Electrochem Commun., 9, 1374 (2007)

4. I. Lisiecki and M. P. Pileni, J. Am. Chem. Soc., 115, 3887 (1993)

5. I. Lisiecki, F. Billoudet, and M. P. Pileni, J. Phys. Chem., 100, 4160 (1996).

6. H. H. Huang, F. Q. Yan, Y. M. Kek, C. H. Chew, G. Q. Xu, W. Ji, P. S. Oh, and S. H. Tang, Langmuir, 13, 172 (1997).

7. L. Qi, J. Ma, and J. Shen, J. Colloid Interface Sci., 186, 498 (1997).

8. H. Ohde, F. Hunt, and C. M. Wai, Chem. Mater, 13, 4130 (2001)

9. N. A. Dhas, C. P. Raj, and A. Gedanken, Chem. Mater, 10, 1446 (1998).

10. R. V. Kumar, Y. Mastai, Y. Diamant, and A. Gedanken, J. Mater. Chem., 11, 1209 (2001).

11. M.-S. Yeh, Y.-S. Yang, Y.-P. Lee, H.-F. Lee, Y.-H. Yeh, and C.-S. Yeh, J. Phys. Chem. B, 103, 6851 (1999).

12. S. S. Joshi, S. F. Patil, V. Iyer, and S. Mahumuni, Nanostruct. Mater, 10, 1135 (1998).

13. A. P. Young and C. M. Schwartz, J. Phys. Chem. Solids, 30, 249 (1969).

14. J. Zhang, J. Liu, Q. Peng, X. Wang, and Y. Li, Chem. Mater, 18, 867 (2006).

15. D. Snoke, Science, 298, 1368 (2002).

16. A. Muramatsu and T. Sugimoto, J. Colloid Interface Sci., 189, 167 (1997).

17. X. Liu, B. Geng, Q. Du, J. Ma, and X. Liu, Mater. Sci. Eng., A, 448, 7 (2007).

18. L. Gou and C. J. Murphy, Nano Lett., 3, 231 (2003).

19. R. Liu, F. Oba, E. W. Bohannan, F. Ernst, and J. A. Switzer, Chem. Mater, 15, 4882 (2003).

20. C. Lu, L. Qi, J. Yang, X. Wang, D. Zhang, J. Xie, and J. Ma, Adv. Mater. (Weinheim, Ger.), 17, 2562 (2005).

21. W. Wang, G. Wang, X. Wang, Y. Zhan, Y. Liu, and C. Zheng, Adv. Mater. (Weinheim, Ger.), 14, 67 (2002).

22. S. Yagi, H. Nakanishi, E. Matsubara, S. Matsubara, T. Ichitsubo, K. Hosoya, and Y Matsuba, J. Electrochem. Soc., 155, D474 (2008).

23. S. Yagi, T. Koyanagi, H. Nakanishi, T. Ichitsubo, and E. Matsubara, J. Electrochem. Soc., 155, D583 (2008).

24. C. M. Criss and J. W. Cobble, J. Am. Chem. Soc., 86, 5385 (1964).

25. W. M. Latimer, The Oxidation States of the Elements and Their Potentials in Aqueous Solutions, 2nd ed., Prentice-Hall, Englewood Cliffs, NJ (1959).

26. O. Kubaschewski and C. B. Alcock, Metallurgical Thermochemistry, 5th ed. revised and enlarged, Elsevier, New York (1979).

27. D. R. Stull and H. Prophet, JANAF Thermochemical Tables, 2nd ed., NSRDS-NBS, Washington, DC (1971)

28. M. Pourbaix, Atlas of Electrochemical Equilibria in Aqueous Solutions, p. 384 Cebelcor, Brüssel (1966)

29. B. Beverskog and I. Puigdomenech, J. Electrochem. Soc., 144, 3476 (1997).

30. C. D. Iacovangelo, J. Electrochem Soc., 138, 976 (1991)

31. C. D. Iacovangelo and K. P. Zarnoch, J. Electrochem. Soc., 138, 983 (1991). 